\title{
Surgery for stage IV non-small cell lung cancer?
}

\author{
Carlos A. Puig, Dennis Wigle \\ Division of General Thoracic Surgery, Department of Surgery, Mayo Clinic, Rochester, MN, USA \\ Correspondence to: Dennis Wigle, MD, PhD. Division of General Thoracic Surgery, Department of Surgery, Mayo Clinic, 200 1st St SW, Rochester, \\ MN 55905, USA. Email: wigle.dennis@mayo.edu. \\ Provenance and Peer Review: This article was commissioned and reviewed by the Section Editor Michael K. Y. Hsin (Department of Cardiothoracic \\ Surgery, Queen Mary Hospital, Hong Kong, China). \\ Comment on: Gomez DR, Tang C, Zhang J, et al. Local Consolidative Therapy Vs. Maintenance Therapy or Observation for Patients With \\ Oligometastatic Non-Small-Cell Lung Cancer: Long-Term Results of a Multi-Institutional, Phase II, Randomized Study. J Clin Oncol \\ 2019;37:1558-65.
}

Submitted Jan 22, 2020. Accepted for publication Feb 17, 2020.

doi: $10.21037 /$ jtd.2020.03.32

View this article at: http://dx.doi.org/10.21037/jtd.2020.03.32

Textbook approaches for the role of surgery in nonsmall cell lung cancer (NSCLC) are straightforward; surgery alone for stage I tumors, surgery followed by adjuvant chemotherapy for stage II disease, a persistent but controversial role as part of multi-modality treatments for stage IIIA disease, but with IIIB and stage IV disease typically being approached as surgical no-fly zones except for rare circumstances. Like most things in life however, disruption is everywhere. The "textbook" paradigm is getting turned on its ear, most profoundly in the setting of limited burden stage IV disease or "oligometastatic" lung cancer.

Historically, limited retrospective case series have suggested a potential role for surgery in limited NSCLC metastatic disease $(1,2)$. Favorable outcomes have been described for the application of surgery to isolated metastases of the brain or adrenal glands in conjunction with removal of the lung primary lesion (3). Although these results have suggested that there may be a subset of patients with limited metastatic disease that could benefit from aggressive local therapy, this concept has remained on the fringe until recent publication of the Gomez trial results (4).

The concept of clinically significant oligometastases was first introduced in 1995 by Hellman and Weichselbaum (5), who proposed that patients with limited metastatic disease might benefit from local therapy. Depending on how you define it, oligometastatic disease is found in approximately $7 \%$ of patients newly diagnosed with NSCLC (6). This problem of definition has been one of the main stumbling blocks to advancing the science. What really constitutes limited or oligometastatic NSCLC? Multiple "consensus statements" have been brought forward (7-9) to capture the idea of a favorable clinical state with evidence of treatment response, more indolent biology, a limited number of disease sites, and therefore the possibility for enhanced disease free and even overall survival (OS) (10).

The dilemma in all of this is that talking heads do not change clinical practice, properly done clinical trials do. Gomez et al. at MD Anderson took the effort to write down a definition and test it in a randomized, phase II clinical trial to formally address the question of whether aggressive local therapy (either surgery and/or radiation) for advanced disease really provides clinical benefit. Their initial report in Lancet Oncology in 2016 (11) from multiple institutions demonstrated benefit for stage IV NSCLC patients with 3 or less metastases, and no progression 3 or more months after systemic therapy (platinum doublet or agents targeting EGFR mutation or ALK rearrangement). In the study, randomization was done (1:1) to maintenance therapy or observation (MT/O), or to local consolidative therapy (LCT) to all active disease sites. Initial trial (11) closed prematurely following accrual and randomization of 49 patients, given that it demonstrated an observed 8-month benefit in progression-free survival (PFS) in the LCT vs. MT/O group. These intriguing findings have held up in the updated results, recently published in the Fournal of Clinical Oncology (12) included OS data, PFS (the primary end-point of the study), and toxicity. During a median follow-up of 
38.8 months, median PFS was 14.2 months in LCT group vs. 4.4 months in the MT/O group $(\mathrm{P}=0.014)$. Median OS was 41.2 months in LCT group vs. 17.0 months in the MT/ $\mathrm{O}$ group $(\mathrm{P}=0.017)$. No additional severe (grade 3 or higher) toxicities were reported in either treatment arm. Survival after progression was also prolonged in the LCT group, 37.6 vs. 9.4 months MT/O; $\mathrm{P}=0.034$ ).

A number of important points are worth noting. First, the OS benefit in the treatment arm that initially was assigned to receive LCT, was observed despite being allowed to crossover from the MT/O arm to the LCT arm at the time of progression. Second, early closure of the study resulted in a smaller sample size and therefore limited the ability to perform subsequent exploratory subgroup analyses as to who benefitted most. Also, importantly, given that this study opened in 2012, it did not include immune checkpoint inhibitors as part of systemic therapy regimens.

Many questions remain. What is the real dividing line (definition of oligometastatic disease) where benefit lies? Will this continue to expand in the immunotherapy era? For which lesions is surgery vs. SBRT best applied? What is the best dose/fractionation regimen for radiation treatment to individual lesions? In the setting of immunotherapy, does focal radiation augment tumor antigenicity and treatment efficacy? How can this approach be reliably applied to routine clinical care? Many trials are now ongoing to address these and other related questions. Kudos to the authors of the Gomez trial for their persistence in completing a real-world, practical study with practice changing results.

\section{Acknowledgments}

Funding: None.

\section{Footnote}

Conflicts of Interest: Both authors have completed the ICMJE uniform disclosure form (available at http://dx.doi. org/10.21037/jtd.2020.03.32). The authors have no conflicts of interest to declare.

Ethical Statement: The authors are accountable for all aspects of the work in ensuring that questions related to the accuracy or integrity of any part of the work are appropriately investigated and resolved.
Open Access Statement: This is an Open Access article distributed in accordance with the Creative Commons Attribution-NonCommercial-NoDerivs 4.0 International License (CC BY-NC-ND 4.0), which permits the noncommercial replication and distribution of the article with the strict proviso that no changes or edits are made and the original work is properly cited (including links to both the formal publication through the relevant DOI and the license). See: https://creativecommons.org/licenses/by-nc-nd/4.0/.

\section{References}

1. Tanvetyanon T, Robinson LA, Schell MJ, et al. Outcomes of adrenalectomy for isolated synchronous versus metachronous adrenal metastases in non-small-cell lung cancer: a systematic review and pooled analysis. J Clin Oncol 2008;26:1142-7.

2. Hu C, Chang EL, Hassenbusch SJ, et al. Nonsmall cell lung cancer presenting with synchronous solitary brain metastasis. Cancer 2006;106:1998-2004.

3. Lopez Guerra JL, Gomez D, Zhuang Y, et al. Prognostic impact of radiation therapy to the primary tumor in patients with non-small cell lung cancer and oligometastasis at diagnosis. Int J Radiat Oncol Biol Phys 2012;84:e61-7.

4. Gomez DR, Tang C, Zhang J, et al. Local Consolidative Therapy Vs. Maintenance Therapy or Observation for Patients With Oligometastatic Non-Small-Cell Lung Cancer: Long-Term Results of a Multi-Institutional, Phase II, Randomized Study. J Clin Oncol 2019;37:1558-65.

5. Hellman S, Weichselbaum RR. Oligometastases. J Clin Oncol 1995;13:8-10.

6. Villaruz LC, Kubicek GJ, Socinski MA. Management of non-small cell lung cancer with oligometastasis. Curr Oncol Rep 2012;14:333-41.

7. Hendriks LEL, Dooms C, Berghmans T, et al. Defining oligometastatic non-small cell lung cancer: A simulated multidisciplinary expert opinion. Eur J Cancer 2019;123:28-35.

8. Reyes DK, Pienta KJ. The biology and treatment of oligometastatic cancer. Oncotarget 2015;6:8491-524.

9. Goldstraw P, Chansky K, Crowley J, et al. The IASLC lung cancer staging project: Proposals for revision of the TNM stage groupings in the forthcoming (eighth) edition of the TNM Classification for lung cancer. J Thorac Oncol 2016;11:39-51.

10. Gerber DE. Oligometastatic Non-Small-Cell Lung 
Cancer: How Should We Define and Manage It? J Oncol Pract 2018;14:32-4.

11. Gomez DR, Blumenschein GR, Lee JJ, et al. Local consolidative therapy versus maintenance therapy or observation for patients with oligometastatic non-smallcell lung cancer without progression after first-line systemic therapy: a multicentre, randomised, controlled, phase 2 study. Lancet Oncol 2016;17:1672-82.

12. Gomez DR, Tang C, Zhang J, et al. Local Consolidative Therapy Vs. Maintenance Therapy or Observation for Patients With Oligometastatic Non-Small-Cell Lung Cancer: Long-Term Results of a Multi-Institutional, Phase II, Randomized Study. J Clin Oncol 2019;37:1558-65.
Cite this article as: Puig CA, Wigle D. Surgery for stage IV non-small cell lung cancer? J Thorac Dis 2020;12(4):1612-1614. doi: $10.21037 /$ jtd. 2020.03 .32 